\title{
Performatividad, liminalidad y politicidad en la práctica teatral del colectivo La Patogallina'
}

\section{Performativity, Liminality and Politicity in the theatrical practice of La Patogallina}

\author{
Fernanda Carvajal \\ Universidad de Buenos Aires, \\ Facultad de Ciencias Sociales. \\ Departamento de sociología. Buenos Aires, Argentina \\ lapidicola@gmail.com
}

Resumen - Este ensayo ${ }^{2}$ busca describir, contextualizar y problematizar, la presentación de la obra El Húsar de la Muerte, que el colectivo artístico La Patogallina realizó como inauguración simultánea del VII FITAM (2001) y de La Moneda como escenario teatral. Para ello, proponemos las categorías de teatralidad liminal, performatividad y politicidad, que permiten concebir este episodio, no ya desde una perspectiva teatral en sentido restringido, sino privilegiando un enfoque transdisciplinario. Estas categorías y la consideración del derrotero ideológico, estético y organizativo del colectivo, entregan claves para comprender cómo la presentación de La Patogallina, atravesada por conflictividades en torno al juicio a Augusto Pinochet, puede ser leída como fisura al espacio festivo/cultural y al consenso normativo que articulaba la «política de apertura» de La Moneda a la ciudadanía.

Palabras clave: performatividad, prácticas colectivas, micropolítica, heterotopía.

Abstract - The following essay tries to analyze and contextualize the exhibition of the play El Húsar de la Muerte, carried out by the artistic collective La Patogallina at the government house of Chile, La Moneda, in the framework of the inauguration of the VII International Festival Theater (FITAM) in 2001. In order to carry out the analysis, we propose the categories of liminality, performativity and politicity which allow conceiving this episode not from conventional theatrical structures, but from a transdisciplinary point of view. These categories plus the ideological, aesthetic and organizational backgrounds of the collective will allow us to understand the bursting of La Patogallina in La Moneda as an event which was marked by the conflicts with the Augusto Pinochet trial. This can be read as a fracture in the festivity/cultural space and the normative consensus that articulated the "politics of aperture» from La Moneda to all citizens.

Keywords:performativity,collective practices,micropolitics, autonomy, heterotopy.

Proyecto núm. 1080492 «Luces brotaban: autorrepresentaciones y actualizaciones de la letra en la literatura y canción chilena (1960-2006)», financiado por el Fondo Nacional de Ciencia y Tecnología, FONDECYT. Dirigido por Rubí Carreño, en el cual participo como tesista.

2 Quisiera dedicar este ensayo a Pío Longo y agradecer, por un lado, la colaboración del colectivo La Patogallina , y por otro, las valiosas observaciones que Ignacio Ramos, Rubí Carreño y Ana Longoni hicieron a este texto, los aportes de Marcelo Expósito y de los demás artistas e intelectuales ligados a la revista Brumaria. 
La palabra performance, en su diversidad de acepciones y derivados, se torna atractiva y a la vez problemática como categoría de análisis. Comprendida a veces como género artístico, otras como práctica cultural o bien como categoría epistemológica, aparece como un concepto intersticial que, a la vez, atraviesa el campo de las artes visuales, el teatro, los estudios feministas o la literatura, obligando a repensar los límites disciplinarios. Es quizá esta cualidad liminal del concepto, la que lo vuelve atractivo para analizar el evento que nos proponemos abordar.

Aún así, ya que aquí analizamos las prácticas de un colectivo teatral, parece pertinente situar brevemente nuestra perspectiva respecto al territorio de la investigación de las artes escénicas, del que este texto entra y sale permanentemente. En las últimas décadas, el estudio de lo teatral aparece atravesado por vertientes que se disputan la delimitación de la disciplina como «disciplina autónoma». Se trata, por un lado, de los Estudios Teatrales que encuentran su principal antecedente en la tradición francesa de semiología teatral (Pavis, 2002) y que proponen la categoría de teatralidad (Barthes) como una espesura de signos que desbordan el lenguaje del texto dramático, signos corporales, visuales, sonoros y por cierto también verbales, que estarían dispuestos para interactuar entre sí ante un espectador. Desde esta vertiente, el énfasis queda puesto en la semioticidad, es decir, en el significado de la puesta en escena, entendida a su vez como sistema de signos, circunscribiendo lo teatral a la parcela de lo estético.

Por otro lado, en un intento por borrar los límites disciplinarios surgen los Estudios de Performance, inscritos en la tradición académica anglosajona. Aunque el vínculo entre teatro y performance también se ha entroncado a las artes visuales, campo donde surge el performance art de la mano de happenings y acciones artísticas, fueron los trabajos que Víctor Turner y Richard Schechner realizaron desde la antropología los que apuntalaron esta directriz de la investigación teatral. A partir de la observación de prácticas rituales, Turner propuso el concepto de lo «liminal», ${ }^{3}$ para designar acciones o situaciones alternativas inscritas en el margen o umbral entre distintos campos. Esta noción fue retomada a su vez por Schechner, quien propuso los conceptos de performance (en términos de un binomio que conjuga eficacia simbólica y entretenimiento) para designar procedimientos circunscritos al ámbito teatral y performance cultural, para designar todas aquellas conductas y ritos presentes en la sociedad que tienen un potencial preformativo, como matrimonios, festividades, deportes o actos políticos.

Desde otra perspectiva, los Estudios Teatrales —especialmente aquellos desarrollados en Alemania-, tomando todavía como punto de partida el concepto de puesta en escena - lo teatral en sentido restringido-, han considerando la categoría de "performatividad» como término opuesto y a la vez complementario a la semioticidad, entendiendo que «en la puesta en escena siempre están presentes lo preformativo y lo semiótico, al mismo tiempo. El teatro siempre realiza no sólo una función preformativa sino también una función semiótica» (Ficher Litche y Roselt, 2008: 123). Así, mientras que semioticidad pondría a disposición del espectador significados a decodificar, la performatividad designaría aquellos momentos de la práctica escénica donde se produce un exceso ite-

Concepto que surge del estudio de las características sociales de los ritos de pasaje de la cultura ndembu de Zambia, que suponen una transición de estados y en los que reconoció cuatro fases: de separación, donde ocurre una función purificadora asociada a cambios curativos; de inversión de los roles sociales; fase liminal, donde se realiza una experiencia en el umbral entre dos mundos (p.e. sagrado/profano); y la de creación de una comunitas, entendida ésta como una antiestructura al modo de sociedades abiertas donde se establecerían relaciones espontáneas. 
rativo de materialidad corporal que, en un giro tautológico, tendería a ser leído como si no significara otra cosa que dicha materialidad. En esta dirección, el concepto de teatro postdramático (Lehmann, 2002) propone comprender el excedente performático - a modo de suspensión del relato escénico producido por la reiteración o desborde de la corporalidad del actor- como resistencia a la interpretación semántica. El problema con estas formulaciones sería que el valor de la performatividad como concepto en fuga hacia otras zonas de la trama social, queda obturado, apareciendo más bien, como una nueva manera de acentuar operaciones autorreferenciales de lo teatral. De ahí que, con Diéguez, consideremos que:

El cuerpo del actor — corporalidad autosuficiente, plantea Lehmann- no es sólo una presencia material que ejecuta una partitura preformativa dentro de un marco autorreferencial y estético. El cuerpo del ejecutante es el de un sujeto inserto en una coordenada cronotrópica, la presencia es un ethos que asume no sólo su fisicalidad sino también la eticidad del acto y las derivaciones de su intervención (Diéguez, 2007: 45).

En la búsqueda de interpretaciones que incluso intentando reactivar el potencial disruptivo, deshabituador de lo teatral, no devuelvan las prácticas performáticas hacia una esfera autorreflexiva y autorrestrictiva, retomamos aquí la perspectiva de dos autoras latinoamericanas, cuyas reflexiones entran en diálogo más estrecho con el episodio que aquí analizaremos. Por un lado, tendremos a la vista el sentido amplio con que Beatriz Rizk define la performatividad en relación a «obras que presentan rupturas y cuestionan los límites entre los géneros (teatro/performance), el arte y la vida (representación/ realidad, espectáculo/público) y que presuponen una posición crítica del autor/actor con respecto al material que utiliza» (2000: 95). Y por otro, retomamos algunas reflexiones de Ileana Diéguez (2007), quien en su estudio sobre prácticas escénicas latinoamericanas de las últimas décadas propone la categoría de «teatralidades liminales» para estudiar prácticas que, «desde el arte», se arriesgan a intervenir en espacios públicos insertándose en dinámicas ciudadanas.

Así, entrecruzando la vertiente antropológica y aquella deudora de las artes visuales, esta autora retoma el concepto de liminalidad de Víctor Turner, para proponer una «teatralidad liminal» como «estado de extrañamiento de la teatralidad habitual», dado por «situaciones donde se contaminan y cruzan la teatralidad y la performatividad, la plástica y la escena, la representación y la presencia, la ficción y la realidad, el arte y la vida. Lo liminal, como lo fronterizo, es de naturaleza procesual; es una situación de canjes, mutaciones, tránsitos, préstamos, negociaciones» (Diéguez, 2004: 39).

Junto a estas perspectivas, consideraremos también otra conceptualización de la performatividad proveniente de los Estudios Culturales, que nos permitirá explorar la intervención de La Patogallina en La Moneda como un evento que puede ser leído no sólo desde el arte, sino como una «intervención política». Nos referimos a la noción de performatividad como categoría epistemológica, tal como ha propuesto comprenderla George Yúdice en su libro La Cultura como Recurso. Este autor retoma la noción foucaultiana de episteme y la teoría de la performatividad de Judith Butler, para comprender lo preformativo como aquellos procesos mediante los cuales la cita o reiteración de modelos normativos constituyen identidades y entidades de la realidad social. El potencial disruptivo de la performatividad estaría relacionado con que el ejercicio de reiteración por el cual todo mandato normalizador produce los fenómenos que regula e impone, engendraría fracasos necesarios. La subversión a la norma se produciría, entonces, cuando una 
variedad de configuraciones incoherentes exceden y desafían el mandato por el cual se generan.

Tomando ese punto de partida, Yúdice postula que «tener en cuenta la performatividad de la normalización es en sí una política» (2002: 367). Así, mientras que los postulados de Butler se refieren a las transgresiones a la identidad de género y la sexualidad, Yúdice amplía esta perspectiva para poner el foco en «la fuerza preformativa mediante la cual las instituciones producen eventos culturales que presuponen y en el proceso normalizan a los no hegemónicos» (367), analizando en cada caso los efectos que dichas prácticas desencadenan. ${ }^{4}$

Nos queda especificar, por último, qué entenderemos por «politicidad». En sus reflexiones sobre la relación entre prácticas artísticas y prácticas políticas, Sueley Rolnik señala que mientras la acción activista se juega en el plano macropolítico de los conflictos sociales $^{5}$ establecidos por la cartografía dominante, la práctica artística operaría en la realidad sensible, adquiriendo un potencial micropolítico que se jugaría en el plano de la subjetividad y el deseo, "el plano de los flujos, intensidades, sensaciones y devenires» (2006: 105). El arte se inscribiría así, en una dimensión "preformativa — visual, verbal u otra- operando cambios irreversibles en la cartografía vigente, que debido a que cobran cuerpo en sus creaciones, hacen que las mismas se vuelvan portadoras de un poder de contagio en su recepción» (105).

Sin embargo, ante la creciente valorización de la institución artística en el mercado cultural global ${ }^{6}$ y la autorrestricción de los circuitos artísticos, Rolnik señala cómo muchos artistas han optado por montar sus dispositivos críticos en el espacio social para crear otros medios de producción y otros territorios vitales (de ahí la tendencia a organizarse en colectivos). Este tipo de prácticas activarían una dimensión macropolítica, que permitiría a los artistas tanto:

respirar la relación viva con la alteridad (es decir con la experiencia estética) como el ejercicio de la libertad de crear en función de las tensiones indicadas por los afectos del mundo [...], lo que tropieza con muchas barreras en el terreno del arte (106).

Son estas reflexiones las que recubren la palabra «politicidad», tal como la empleamos al revisar la genealogía de La Patogallina y su intervención en La Moneda.

Retomando entonces el panorama que hasta aquí hemos trazado, pensamos que el análisis del trabajo de La Patogallina debe contemplar los aspectos preformativos y semánticos —-más convencionalmente teatrales — de sus obras, pero desde una perspectiva que no se restrinja sólo al análisis de las poéticas.

Así, habría que tener a la vista, por un lado, que las obras de este colectivo, que prescinden del texto dramático en sentido convencional, proponen un teatro visual de compleja elaboración estética. Sin abandonar una investigación en lo coreográfico y la

$4 \quad$ Así, por ejemplo, Yúdice propone pensar cómo se han modificado las representaciones de lo popular en Latinoamérica a partir de la performatividad que la relación entre lo público y lo privado adquiere en algunas prácticas de ocupación del espacio público, como el Carnaval Brasileño.

5 Se entiende, conflictos de clase, raza, género, medio ambiente u otros.

6 Que podemos ver en el campo de las artes escénicas, en el ámbito de los festivales internacionales, concebidos como instancias de internacionalización del teatro nacional y de su inserción en el mercado global, además de una forma de participar en el mercado cultural global, valorando las ciudades, tal como sucede con el Festival Internacional Santiago a Mil, que no por nada cambió la palabra «Teatro» por «Santiago». 
expresión corporal (con guiños a la danza y a recursos circenses), asume también una exploración teatral del lenguaje cinematográfico, tal como se observa en las obras El Húsar de la muerte (2000) y 1907, el año de la flor negra (2004).

Al mismo tiempo, las prácticas escénicas de La Patogallina exceden las estructuras teatrales tradicionales, proponiendo distintas formas de "acción teatral», que entran en contacto sutil con el happening, el environment, las instalaciones visuales. Así lo expresan privilegiadamente obras como A Sangre e Pato (1996), Mapocho no olvida (2000) y Karrocerías (2001). Pero también se puede ver en el trabajo artístico de La Patogallina un proceso de traducción de las prácticas y procedimientos militantes/activistas hacia la práctica artística, asociado a experiencias previas de algunos de los integrantes del colectivo en el escenario de la cultura de resistencia de los ochenta. Se trata de eventos y acciones heterodoxas, como las intervenciones realizadas en el funeral de Gladys Marín, la participación de La Patogallina Sounmachin en el proyecto Rock y Rejas o la exhibición de El Húsar de la Muerte en La Moneda, a la que dedicamos este texto. La indiscernibilidad entre recursos artísticos y militantes que parecen fecundarse unos a otros, dan lugar a acciones que se insertan en las dinámicas ciudadanas, expuestas a ser atravesadas por los acontecimientos de lo social, permitiendo repensar tanto las nociones convencionales en torno al teatro como en torno a la política.

\section{UNA GENEALOGÍA MIXTA}

Antes de analizar la acción teatral con que La Patogallina irrumpió en La Moneda, haremos un trazado de la genealogía de las experiencias y aprendizajes previos que impregnan su trayectoria artística, pues nos parece que el episodio en La Casa de Gobierno no resulta del todo comprensible sin tener a la vista ese acervo de vivencias y referentes. Se torna necesario "construir esas genealogías y establecer e intercambiar relatos producidos desde su interior, que respondan a su propia naturaleza, no para congelar las experiencias sino para impulsarlas, ramificarlas y multiplicarlas, haciéndolas proliferar atravesando ese contexto de contradictoria visibilidad institucional» (Corbeira y Expósito, 2005).

Desde su constitución como colectivo, La Patogallina ${ }^{7}$ manifiesta un desencaje respecto de las redes, modalidades y escenarios en los que se consolidan los grupos teatrales en Chile. El grupo nace el año 1996, y ha estado conformado por artistas de distintas disciplinas — artistas plásticos, músicos, actores, poetas-. Sus miembros entran en contacto a través de diversas vías, entablando redes a través de organizaciones barriales y culturales alternativas, que se sitúan al margen tanto de la educación formal como de espacios promovidos por las políticas culturales del Estado.

La Patogallina tiene, en efecto, un origen mixto: algunos de sus miembros son autodidactas y otros tuvieron formación en escuelas e institutos teatrales, ${ }^{8}$ que no gozan del

Al momento de realizar esta investigación, los integrantes de La Patogallina eran: Rodrigo Rojas, Eduardo Moya, Cecilia Canto, Martín Erazo, Alejandra Muñoz, Gonzalo Mella, Cael Orrego, Victoria González, Sandra Figueroa, Antonio Sepúlveda, Pilar Salinas, Carol Mardones, Sergio González y Jaime Molina.

8 La Mancha: Escuela Internacional del Gesto y la Imagen, Instituto Profesional Teatro La Casa y Escuela de Teatro Imagen. 
reconocimiento del Ministerio de Educación. Así, los integrantes del colectivo son ajenos a la tradición modernizadora de los Teatros Universitarios; tradición cuyos fundamentos están fuertemente arraigados en la promoción de una dramaturgia nacional y la profesionalización y especialización de los distintas disciplinas involucradas en el oficio teatral (Pradenas, 2006). ${ }^{9}$

El colectivo emerge desde una posición excéntrica en un campo teatral crecientemente academizado. Aun así, es posible emparentarlo, como ha hecho en general la crítica, a otra herencia teatral, estableciendo filiaciones entre La Patogallina y dos grupos emblemáticos de la escena nacional: el Gran Circo Teatro de Andrés Pérez y al Teatro del Silencio de Mauricio Celedón —dos poéticas que a su vez, han sido leídas como una irradiación de teatralidades metropolitanas, debido a la formación que Pérez y Celedón tuvieron con Ariane Mnouchkine y el Theatre du Soleil en Francia (Griffero, 1992)—.

Un texto publicado recientemente, Viajando y buscando eternamente, señala así que entre las obras de La Patogallina, se pueden ver «las huellas del Gran Circo Teatro, de Andrés Pérez - el circo, los espectáculos callejeros-y el Teatro el Silencio, de Mauricio Celedón - acrobacias, el frenético ritmo de la música y el tinte grotesco y expresionista de maquillajes y decorados—»(Oyarzún y Opazo, 2008: 22). Este texto es uno de los pocos, dentro de la crítica especializada, que ha incluido a La Patogallina en sus análisis. Ciertamente, algunos de los miembros del grupo tuvieron experiencias directas con el Teatro del Silencio, donde participaron como actores. Sin embargo, una arqueología de los «restos» artísticos recogidos en la práctica teatral de La Patogallina, obliga a traspasar los límites de lo teatral para buscar entre fuentes más heterodoxas y olvidadas.

\section{LOS 80: DESOBEDIENCIAS CALLEJERAS (HIJOS) DE LA PROTESTA}

Una parte importante de los miembros fundadores de La Patogallina, conformada por Gloria Salgado (ex-integrante), Sergio Pineda (ex-integrante), Eduardo Moya y Rodrigo Rojas, se conocieron siendo adolescentes, pues compartían una pertenencia barrial: todos nacieron y se criaron en distintas poblaciones en la zona norte de Santiago, en Conchalí. En torno a 1986 y 1987, cuando la mayoría de ellos todavía cursaba el liceo, algunos iniciaron su militancia en las Juventudes Comunistas - la que fue abandonada, en casi todos los casos, con la recuperación de la democracia-. Paralelamente, el año 1986 surgió La Escala, un grupo de jóvenes que tenían la voluntad de hacer un trabajo social y político a través de un soporte artístico, la pintura mural, en un gesto de desobediencia ligado a la necesidad ideológica de ocupar el espacio urbano controlado por la dictadura. Aun así, el Taller La Escala no era un grupo ligado orgánicamente a un partido, si bien algunos de sus integrantes tenían filiación partidaria.

\footnotetext{
$9 \quad$ Al respecto, Pradenas señala: «la acción desarrollada por los teatros universitarios constituye la piedra angular del movimiento de renovación del teatro chileno [...]. Promoviendo eel desarrollo de la dramaturgia nacional —organizando talleres de creación, encuentros teatrales, ‘concursos de obras de teatro> e incorporando autores chilenos a su repertorio- los teatros universitarios generan <circuitos pluridisciplinarios reagrupando a todos los participantes en la creación y producción de un espectáculo teatral. Cada una de las disciplinas implicadas en la producción y representación del espectáculo teatral adquiere un status artístico profesional universitario»: directores y actores se transforman progresivamente en ‘artistas profesionales> las artes escénicas comienzan a enseñarse en las escuelas universitarias, el teatro se impone como un hecho de arte» (2006: 306).
} 
Eduardo Moya (Snoopy) señala que era «una organización social, cultural. Pintábamos murales políticos, murales culturales. Y ahí adquirimos una dinámica tanto política como social de actividad, de agitación». ${ }^{10}$ Como señala Longoni (1999), en la historia del muralismo chileno aparecen dos tradiciones. Por un lado, la del mural perenne, "hecho con materiales nobles y perdurables que decoran los muros de las instituciones de la $\mathrm{Na}$ ción», cuyos antecedentes se encuentran en el muralismo mexicano. ${ }^{11}$ Y por otra, la del mural efímero, "callejero, realizado por militantes en condiciones de riesgo» (24-5), más cercano a la intervención política que a la manifestación artística, y que tiene su referente en la Brigada Ramona Parra. La Escala pertenecía más bien a la segunda vertiente, tal como señala Salgado:

Era un grupo cultural bien espontáneo, de gente de ahí de la población, que pintábamos murales. En general casi todos eran pintores de calle, muralistas. Era la época cuando estaba finalizando la dictadura del Pinocho y pintábamos murales escondidos. Se llamaba La Escala, porque nos juntábamos en una escala. Eran uno de esos blocks dúplex. Nos conocemos desde esa época, bien chicos (GS). ${ }^{12}$

Ninguno de ellos estaba en ese momento vinculado al teatro. En junio del año 1988, según algunas versiones, dentro del contexto de la militancia en las Juventudes Comunistas (JJCC), según otras, debido a un volante que llegó a La Escala, Gloria Salgado y Sergio Pineda conocen a Roberto Pablo Fariña, uno de los precursores, junto a Andrés Pérez, Juan Edmundo González y Andrés Pavez, del teatro callejero "profesional» (Costa, 2002) a comienzos de los años ochenta. ${ }^{13}$ Fariña dirigía en ese momento la Escuela Nacional de Teatro Callejero (ENATECA), ubicada en la calle Concha y Toro $\mathrm{n}^{\circ} 54$, desarrollando un trabajo que ponía acento en el trabajo corporal y en las técnicas circenses: «se realizaban clases de zancos, máscaras, acrobacia, voz, actuación, maquillaje, expresión corporal» (Costa: 80).

Pero en realidad, más que un espacio regular de formación, la ENATECA fue una instancia para congregar al grupo de jóvenes que junto a Fariña formaron el grupo Sociedad Anónima. Salgado y Pineda conocieron en ese contexto a Cecilia Canto, y los tres formaron parte de la compañía entre 1988 y 1990. Fue ahí donde tuvieron sus primeros aprendizajes en torno a lo teatral y la primera obra que hicieron fue Te pasaste la película o te hiciste la América (1989), un montaje callejero de 50 minutos de duración, que presentaban en la intersección de la calle Huérfanos con el Paseo Ahumada. ${ }^{14}$ Sociedad Anónima era heredera, en parte, de la estética y los contenidos del teatro callejero de disidencia de los primeros años ochenta. Así, respecto a su concepción teatral y a las técnicas utilizadas, Fariña señalaba que «el método se construía día a día, teniendo muy

10 Entrevista realizada a Eduardo Moya, en noviembre del 2006. En adelante citada como (EM). Algunas de las entrevistas aquí referidas, entre ellas ésta, fueron realizadas en el marco del proyecto Fondart $n^{\circ}$ 48927. Ello se especificará cuando sea el caso.

11 Emblemático en este sentido, es el Mural «Muerte al Invasor» que David Alfaro Siqueiros pintó en Chillán en 1942.

12 Entrevista personal, realizada en septiembre del 2008, de ahora en adelante, citada como (GS).

13 Siendo estudiantes de Artes Plásticas en Concepción, Roberto Pablo formó el año 1981 el Teatro Urbano Experimental. El año 1986 se habría trasladado a Santiago, donde se integró al Teatro Urbano Contemporáneo (TEUCO), cuando era dirigido por Juan Edmundo González. Tras la disolución del TEUCO formó en 1988, la ENATECA (Costa, 2002).

14 Según el testimonio de Fariña, el montaje estaba inspirado en Roman Photo (1987) del Royal de Luxe, simulaba un set cinematográfico de filmación y tenía como base un texto escrito por el propio Fariña. 
presentes todas las técnicas que nos sirvieran. El teatro callejero se hace pensando en el público, cómo cautivarlo, por eso debe ser espectacular» (Costa, 2002: 81). Por su parte, Cecilia Canto recuerda:

En Huérfanos con Ahumada armábamos nuestro ruedo, con nuestros zanquitos y ahí nos íbamos cambiando de ropa y actuando, si te ibas preso te ibas preso, a mí nunca me tocó. Era súper artesanal, hablando fuerte. El estilo teatral era súper distinto, era juglaresco total, súper juglaresco, y bien político, entrando en lo cuático [es decir, exagerado] (CC2). ${ }^{15}$

Roberto Pablo Fariña colaboraba en esos años con el Partido Comunista, por lo que Sociedad Anónima intervino en algunos eventos y protestas organizados por el partido: «empezamos a intervenir en zancos, empezamos a intervenir con maquillaje, empezamos a intervenir con algunas propuestas, con máscaras en altura, máscaras sobredimensionadas [...]. Nunca fuimos, obviamente, «la» compañía de las Juventudes Comunistas, pero sí nos asociaban directamente con ellos» (RP). ${ }^{16}$ Gloria Salgado (que para ese entonces había abandonado la militancia partidaria, pero seguía formando parte de La Escala), recuerda que participaron en los actos de conmemoración que se realizaban cada 11 de septiembre en el Cementerio General, y también en una gira al norte del país organizada por el PC en el marco de la Campaña del No, previa al plebiscito de 1988:

Yo sabía que el Roberto Pablo militaba, y yo de alguna manera aceptaba ir a las cosas que él invitaba, porque simpatizaba de todas maneras como con la idea, pero yo no formaba parte, yo no trabajaba políticamente, así directamente con el partido como el Roberto (GS).

Tanto Gloria Salgado, como Cecilia Canto, ${ }^{17}$ señalan en sus testimonios que entienden su paso por Sociedad Anónima como una experiencia importante en términos de iniciación, pero ven con distancia ese proceso, así como la estética y la forma teatral de aproximarse a lo político - como algo subordinado a la obra como tema- que caracterizaba el lenguaje teatral ahí explorado. Quizá porque Sociedad Anónima, como grupo teatral nacido en la coyuntura de la "transición», estaba marcado a nivel estético e ideológico, por la impronta de formas antiguas que no llegan a extinguirse y nuevas estéticas que no alcanzan aún a consolidarse. Lo cierto es que en la distancia hacia esa estética marcada por las actrices, se puede ver una ruptura generacional respecto a la experiencia teatral de Roberto Pablo Fariña, originada y arraigada al espíritu contracultural de los inicios de la dictadura.

Podemos notar que ello también se relaciona con la asimilación de la experiencia de militancia partidaria: tanto Gloria Salgado, como Cecilia Canto, cuentan que el término de su militancia tuvo que ver, entre otros factores, con un desencanto y una disconfor-

15 Entrevista a Cecilia Canto, realizada en octubre del 2007 en el marco del proyecto Fondart $n^{\circ} 48927$. En adelante, citado como (CC).

16 Entrevista personal a Roberto Pablo Fariña, junio 2008. De ahora en adelante citado como: (RP). Roberto Pablo recuerda que conoció a Salgado, Canto y Pineda, en intervenciones que él organizaba de protestas callejeras y señala que habrían participado un espectáculo dirigido por él, que abrió la inauguración del VIII Congreso de las Juventudes Comunistas, realizado en el Estadio Chile, a fines de los años ochenta.

17 No fue posible entrevistar a Sergio Pineda, que en el momento de nuestra investigación se encontraba radicado en La Serena. 
midad con la "organización-partido». ${ }^{18}$ Estas discordancias o frustraciones, que pueden estar en la base de las versiones contradictorias sobre las fechas y en la atenuación del significado atribuido a sus experiencias de militancia - la idea de que fue una opción pasajera influida por la herencia familiar, o bien, algo asociado a la edad-, se relaciona con lo que Salazar y Pinto (2002) han designado como «desencanto democrático».

Del fragmento nos interesa retener la idea del repliegue de los jóvenes hacia lo microcolectivo y su desconfianza de lo institucionalizado. Ello puede verse como expresión de una estructura de sentimiento (Williams, 1980) ${ }^{19}$ que se configuraba en paralelo a la crisis de la comprensión de lo político-ideológico como un bloque armado en torno a un objetivo claro (derrocar la dictadura). Una "otra politicidad", asociada a zonas menos rígidas, en un giro hacia lo micropolítico, es lo que observamos en las «experiencias de tránsito» de este sub-grupo de miembros que luego darán origen a La Patogallina: siempre en una búsqueda en torno a lo colectivo, abandonan la militancia partidaria para unirse a espacios más asociativos, horizontales y creativos como La Escala, o intervenir/colaborar desde afuera, con partidos o movimientos sociales, como es el caso de la relación que entabló Sociedad Anónima con el PC o el movimiento de derechos humanos. Prácticas que podemos entender en términos de una micropolítica, en el sentido de «fuerzas» que tienen la posibilidad de "agitar la realidad, disolviendo sus formas y engendrando otras en un proceso que abarca el deseo y la subjetividad»(Rolnik, 2005: 477).

Así lo expresan las palabras de Gloria Salgado:

Creo que los partidos son instituciones, y ahí no creo que haya ninguno que se salve [...]. Creo que la lucha se puede dar a través de lo que uno hace como artista, de cómo uno baila, de cómo uno aprende a bailar, cómo uno enseña a bailar, de cómo hace el teatro, de lo que dice en el teatro, de cómo educas a los hijos (GS).

Este cambio hacia otras politicidades, también tiene un correlato en las formas de lo colectivo que adquirieron las distintas prácticas artísticas emprendidas por estos teatristas antes de dar origen a La Patogallina.

\section{LOS 90: TEATRO PUNK}

El año 1991, Cecilia Canto comienza a estudiar teatro en el instituto Bertolt Brecht y poco después empieza a colaborar en el Teatro Provisorio de Horacio Videla, donde

18 Cecilia Canto cuenta: «Para el VIII Congreso de la jota, yo estaba súper ilusionada porque pensé que a nivel de base se iba a discutir y todo y después me di cuenta de que ya estaba todo cortado. Entonces no... o sea, uno está en la calle peleando y daba lo mismo. Y eso me desilusionó, a nivel de organización, no a nivel de ideas. Porque pa' mí el comunismo es algo fuerte, es una cosa que llevo conmigo. Pero creo que la organización está maniada (sic), por eso me fui» (CC2). Puede ser que Cecilia Canto se esté refiriendo, en realidad, al XV Congreso del PC, realizado en mayo de 1989.

19 Para Williams, las «estructuras de sentimiento», son un concepto clave para comprender el cambio cultural. Son una suerte de «conciencia práctica» que expresaría aquellos «significados y valores tal como son vividos y sentidos activamente, y las relaciones existentes entre ellos y las creencias sistemáticas o formales, que en la práctica, son variables (incluso históricamente variables) en una escala que va desde un asentimiento formal con una dimensión privada, hasta la interacción más matizada existente entre las creencias seleccionadas e interpretadas y las experiencias efectuadas y justificadas» (1980: 155). 
trabaja como actriz en El Sueño de Clara (1993). Gloria Salgado, que por su cuenta también realizó estudios en danza, ingresó —en el marco de los talleres impartidos por Mauricio Celedón en las Jornadas de Purificación del Estadio Chile (1990) - al Teatro del Silencio. ${ }^{20}$

Por su parte, Eduardo Moya, Patricio Pimienta y Rodrigo Rojas, participan a partir del año 1992 en una agrupación artística, barrial, sucesora de La Escala llamada El otro Circo. Eduardo Moya cuenta:

Tuvimos otra brigada con esto del nuevo circo, hacíamos murales, hacíamos intervenciones en las calles, hicimos una intervención de pintar las sombras de los grifos en toda la población. El Pato Pimienta era poeta, era escritor y (sic) hicimos también unos trabajos de antipoesía, también participaron grupos de ahí emergentes, era toda una movida ahí y ese era un grupo que comandaba la cosa (EM2). ${ }^{21}$

El otro Circo fue uno de los antecedentes del movimiento de malabaristas que se formó en Santiago a mediados de los noventa, en una «toma» espontánea de la plaza Juan Sebastián Bach, al costado del Museo de Arte Contemporáneo (MAC), en el Parque Forestal. Así, después de estas experiencias por separado, el subgrupo que luego fundaría La Patogallina —-Salgado, Canto, Rojas, Moya, Pineda, Pimienta ${ }^{22}$-, se vuelve a reunir para dar inicio al movimiento interbarrial e intercomunal que entre jóvenes de distintas procedencias, configuraron un «espacio para expresarse libremente, interactuar y reforzar su identidad» (Neira y Segovia, 2005: 168). Los miembros de La Patogallina encontraron ahí un lugar de aprendizaje «informal», vinculado a las técnicas del nuevo circo, a la vez que un nuevo vínculo entre expresión artística y espacio urbano.

En ese contexto, se une al grupo Martín Erazo quien en general ha asumido el trabajo de dirección al interior del colectivo. Erazo estaba iniciando estudios teatrales en La Mancha, Escuela internacional del Gesto y la Imagen, y había estudiado cine en el instituto Arcos y luego en Cuba. Era también en ese momento, vocalista del grupo de rock Entrekalles, de origen barrial en Peñalolén. La música, el rock de la mano de Erazo, pero sobre todo de los músicos que se unen progresivamente al grupo: Cristián Pino, Alejandra Muñoz, Dángelo Guerra, Rodrigo Latorre, dieron vida a la banda La Patogallina Sounmachin, uno de los «proyectos satélite» desarrollados por el colectivo en paralelo a la actividad teatral.

Por un lado, La Patogallina Sounmachin ${ }^{23}$ adquiere un rol fundamental en las estrategias de autogestión del colectivo, en la organización de recitales y fiestas. Y también, el

20 Gloria Salgado cuenta: «a mí me gustó harto ese encuentro con el Mauricio porque él trabaja harto como desde las emociones y eso fue como una concepción bien nueva. Y yo creo que mi primer contacto profundo con el teatro fue ahí, en el trabajo desde la emoción» (GS).

21 Entrevista a Eduardo Moya, en enero del 2009. Moya señala que este grupo también estaba conformado por militantes de organizaciones políticas y barriales vinculadas a la comuna del Gran Conchalí.

22 Cecilia Canto, cuenta: «El Sergio Pineda es uno de los impulsores del Parque Forestal, con el Nico Allende. Vinieron del Teatro el Silencio y cacharon que en Francia los cabros se juntaban a hacer malabares y trajeron la idea. Y en un principio éramos nueve cabros que nos juntábamos ahí a tirar unas pelotitas echas así con mijo, bien improvisadas. Y ahí estaba el Snoopy, el Rana, el Pineda, yo y la Gloria. Éramos re pocos, nueve, después fuimos quince, y de ahí se fue agrandando» (CC2).

23 Es interesante mencionar similitudes en el derrotero de algunos de los miembros de La Patogallina entre la década de los ochenta y los noventa, y el de muchos grupos de la escena punk nacional, como por ejemplo, Fiskales ad hoc; donde Rubén Darío Urzúa, el bajista, fue militante de la JJ.CC: «antes de convertirse en punk, éste [Rubén Darío Urzúa] había militado en las Juventudes Comunistas. En algún momento llegó a ser ‘buzón` del Frente Patriótico Manuel Rodríguez» (Contardo y García, 2005: 221). O bandas surgidas 
rock se hará presente de manera constante en la musicalización y por lo tanto en la teatralidad de las obras. En efecto, fue justamente la fusión entre una estética del nuevo circo y una «energía rockera», una "energía incisiva, violenta", lo que marcó el sello del primer montaje del grupo: A Sangre e’ Pato (1996), catalogado espontáneamente como "teatro punk». Erazo señala: "Era un teatro punk, con fuerza y visceralidad. Ahora ello se ha ido modificando pese a que aún mantenemos esa estética de choque» (Ramírez, 2004).

Pero además, la práctica artística de La Patogallina concebida en sentido amplio - la reivindicación, como veremos, de la auto escuela, la autoproducción de discos y de todo el merchandising del grupo- encuentra resonancias en el discurso punk, específicamente con todo lo que este movimiento recoge de la tradición política anarquista y contracultural a partir de la consigna del do it yourself. La permanente presencia de la letra «k» en toda la gráfica y consignas del colectivo aparecen como seña de esta filiación.

El trazado de una genealogía mixta que intercala experiencias organizativas vinculadas a lo teatral, pero también a lo militante, encuentra significativa expresión en el «nombre» de la compañía: Patogallina, "patricio-cobarde», aludía una consigna de derecha, que había aparecido en los muros callejeros en el marco de las primeras elecciones presidenciales tras la dictadura. Hacía referencia a la negativa de Patricio Aylwin a participar en un debate televisivo con el candidato de la derecha, Hernán Büchi. El reciclaje de la cita callejera (inscripción de una voz colectiva, condensadora de la oralidad, del rumor, de frases vedadas por el discurso hegemónico), que en este caso contiene la animalidad como signo y el muro como soporte urbano, es un acto (auto) paródico (en especial por el artículo «La» que designaba a un grupo, conformado en un primer momento, solo por hombres); ejercía también un corrimiento de las consignas de izquierda tradicionales de modo similar a la de grupos punk de la escena under de los ochenta (como Los Fiskales ad hoc o los Pinochet Boys, que arrebatan al enemigo —a las «fuerzas del orden»— sus nomenclaturas) y remarcaba un origen fugitivo, ajeno al espacio de formación universitaria. ${ }^{24}$

\section{LA RECUPERACIÓN DEL COLECTIVO}

En La Patogallina la familia estaba muy involucrada, o sea el grupo estaba muy involucrado en la familia de cada uno y cada uno estaba involucrado con la familia de los otros. Al mismo tiempo había una afinidad ideológica, y yo creo que eso también fue lo que nos unió, no solamente la amistad.

Gloria SAlgado

La recuperación de la democracia parecía haber instalado en el sentido común, la idea de que las pulsiones colectivas fueron irremediablemente fracturadas, desmembradas, disueltas. Lo colectivo entendido en términos de horizontalidad, asociatividad, partici-

en la comuna de Conchalí, como Faltan Money’s, Arkólikos Anónimos, Ateos Gracias a Dios y los ya famosos Sinergia (dato aportado por el historiador Ignacio Ramos).

24 La síntesis animal del nombre, pato-gallina, adquiere además significación visual en la gráfica del grupo, en especial en la imagen que parodia al escudo nacional. En ella se reemplaza al cóndor y al huemul, por el pato y la gallina —entre ambos, la garra, dando un sentido de "peligro» al carácter de animal doméstico del pato y la gallina, además de un cariz de extrañamiento- y la consigna "por la razón o la fuerza", parafraseada como "por la razón o la kresta». El nombre La Patogallina, como marca de origen expresa hibridez, la mezcla de las distintas texturas artísticas, teatrales e ideológicas que conviven en el colectivo. 
pación y autogestión, aparece así peyorativamente designado como residuo. En efecto, lo colectivo puede entenderse como una forma «residual» (Williams, 1980), en términos de quiebre o rotura que remite a un tiempo anterior, "pero» en el sentido que, como diría Walter Benjamin, no todo pasado se ha realizado y puede volver a irrumpir en forma de fragmentos no asimilados por el poder, que todavía pueden ser recuperados en su potencialidad. Así nos detendremos en el modo cómo La Patogallina recupera y redefine la figura del colectivo artístico.

En una entrevista realizada a Ramón Griffero el año 2006, éste se refería al concepto de compañía como una figura obsoleta, propia de los años setenta y ochenta, asociado a la modernidad, donde la identidad grupal se sostenía principalmente en base a una «unión ideológica»:

Cuando se quiebran las ideologías, también tiene que ver con que existía el hippismo, la cosa colectiva, comunitaria. Cuando eso desaparece, hay grupos, como La Patogallina, que siguen existiendo, pero con modelos antiguos, que ya no son del teatro contemporáneo. Porque el teatro contemporáneo ya no se construye a partir del concepto de compañía, porque «la nueva estructura artística de creación ya no se basa en las compañías〉 (RG). ${ }^{25}$

Para Griffero, la nueva estructura artística de creación consistiría en autorías escénicas vinculadas a «directores», donde la creación dejaría de estar atada a un modelo pre-establecido (como por ejemplo, el modelo brechtiano), según el cual «las opciones artísticas estaban ligadas a las opciones ideológicas ${ }^{26}$ al modo de los grupos de creación colectiva de los setenta y ochenta - junto a los cuales ubica, indirectamente, a La Patogallina-. Por el contrario, la figura del autor-dramaturgo, que propone cada vez, a partir del texto dramático su «modelo de autor», haría posible una reelaboración constante de los lenguajes, de modo que «el teatro chileno empiece a crecer a partir de sí mismo, y no a partir de la fotocopia del teatro europeo, constituyendo un teatro con mayor identidad» (RG). Se trata de un discurso que expresa un sentido común más extendido que sería necesario revisar, pues arbitrariamente encolumna de un lado, la figura del autor y del texto como requisitos para un «teatro nacional» y del otro, asocia lo grupal y la creación colectiva a procedimientos obsoletos y a la reproducción de «modelos extranjeros».

En la medida que el teatro de La Patogallina no se ajusta al modelo de organización y producción teatral que privilegia el texto y la figura autoral, Griffero añade:

La Patogallina no trabaja con texto. Pero hoy nadie trabaja con improvisación colectiva. La época de la creación colectiva también es una cuestión de los 70. [...] El peso de una escritura dramática hoy día es un peso más fuerte, también hay teatro-danza, pero ahí no hay texto: «eso es otro género». Estamos hablando de dos géneros diferentes. De hecho, el impulso del teatro circo que quiso hacer Andrés Pérez, desapareció. Por no tener texto, se esfumó. El Teatro del Silencio en realidad es mimo [...] entonces, en realidad ¿a qué le ponen teatro?; porque es otro género. El teatro de dramaturgo es el teatro de texto. Después vendrá el cabaret, la danza, la comedia del arte, muchas otras versiones por supuesto. Entonces, en realidad La Patogallina no es un teatro de dramaturgos, se liga con otros... por eso es incomparable (RG).

25 Entrevista personal, realizada a Ramón Griffero en noviembre del 2006, en el marco del proyecto Fondart $n^{\circ}$ 48927. En adelante citada como (RG).

26 Podemos preguntarnos, en todo caso, si es posible concebir las opciones artísticas como algo no ligado siempre y al mismo tiempo, a opciones ideológicas. 
Sin embargo, La Patogallina inscribe otra modalidad de concebir la autoría y el proceso creativo. No se trata de la fotocopia del modelo elaborado genialmente por un maestro, ${ }^{27}$ pero tampoco de la elaboración de un texto dramático que "gatille otra forma de actuar y otro espacio» (RG). Con ecos en las experiencias de auto-organización y autogestión que marcan su pre-historia, La Patogallina propone una manera de trabajar que otorga un rol fundamental a lo autodidacta: la "autoescuela ${ }^{28}$ aparece así como «modelo de proceso creativo" para cada nueva obra. Entendida a la vez como instancia de creación y aprendizaje, es a partir de esta modalidad, que recuerda al antiguo taller artesanal, que se produce para cada espectáculo, un modelo actoral, escenográfico, plástico y musical, donde el texto, a modo de guión o pauta, no pre-existe al proceso de improvisación de los actores. Ante todo, el colectivo niega el encasillamiento de su poética en una fórmula fija: «no hay un manifiesto que diga nuestra línea de trabajo, entonces está por verse para qué lado tiramos y para cuál no [...] Sí tenemos ciertas líneas de conducción, cierta manera de trabajar y eso nos va a dar la cualidad» (EM).

Tampoco puede igualarse mecánicamente La Patogallina a los grupos de creación colectiva o de teatro callejero de los ochenta. Para Soledad Lagos, la necesidad de recuperar un «espacio democrático perdido» (1994: 224), estaba en las bases de la actividad teatral de esos años. Señala que «la disidencia y la carencia en el teatro de creación colectiva de los ochenta» son «términos sinónimos de motor de las búsquedas estéticas de forma y contenido» (230).

La recuperación de la democracia trajo consigo un «desencanto», que afectó las formas organizativas e introdujo cambios en la comprensión de las entidades colectivas, que se redefinieron, pero no desaparecieron. Como señalan Salazar y Pinto, en un plano que no se circunscribe sólo a lo artístico, en los primeros años de democracia se produjo un giro en las formas colectivas asumidas por los jóvenes: «la participación se reanudó asociándose a los espacios identitarios donde se fragua la cultura de «lo nuestro», entendiendo por «lo nuestro lo que no fue derrotado, ni por los militares, ni por la transición política» (2002: 283).

Los cambios que llevaron al «desencanto democrático», se expresan en la política de consensos instaurada por la Concertación, que generó pactos entre mercado y tecnocracia, entre progreso y desmemoria, terminando por asentar y profundizar las políticas neoliberales diseñadas por la dictadura. Este proceso puede entenderse en diálogo con lo que Rolnik ha entendido como la emergencia del «capitalismo cognitivo» o «capitalismo cultural $»^{29}$ en las sociedades latinoamericanas postdictatoriales:

27 Como insinúa Griffero al referirse a La Patogallina: «voy a trabajar con Barba, o la Mnouchkine, como Andrés Pérez» (RG).

28 Un proceso cuyo principal motor son los «talleres» — de movimiento, cine, actuación y voz, dictados por los propios integrantes del grupo o «invitados»—, profesores de danza, expertos en determinadas temáticas, payasos, etc. Además, "procesos de investigación» que involucran tanto investigación histórica y de archivo, como la exploración en distintos códigos escénicos, que contribuyen a la búsqueda de un lenguaje particular para cada nuevo montaje. Se trata de una modalidad colectiva de trabajo que consiste en la socialización de los saberes en juego en cada uno de los roles del proceso creativo, que hace productiva la diversidad de oficios de los integrantes, desjerarquizando las tareas y disolviendo con ello la necesidad de distinguir entre profesionales/autodidactas, técnicos/artistas, distinciones vinculadas a la especialización propia de la tradición universitaria.

29 En los centros metropolitanos, éste ha sido indicado como un nuevo estado del capitalismo asociado a un sistema postfordista de organización del trabajo, en el cual el capital creativo y de innovación de los sujetos se valoriza crecientemente. Dejando atrás el patrón de subjetividad fordista y disciplinario, el capitalismo cognitivo se asociaría a una subjetividad flexible, heredera de la fuerza de creación y la libertad experimental de los movimientos contraculturales de los sesenta y setenta, pero que ha sido rufianizada, 
En su penetración en contextos totalitarios, el capitalismo cultural sacó ventaja del pasado experimental, especialmente audaz y singular en estos países, pero también y sobre todo de las heridas que en las fuerzas de creación causaron los golpes sufridos. El nuevo régimen se presenta no sólo como el sistema que acoge e institucionaliza el principio de producción de subjetividad y de cultura de los movimientos de los años sesenta y setenta, como fue el caso en Estados Unidos y en los países de Europa Occidental. En los países bajo dictadura, dicho nuevo régimen gana un plus de poder de seducción: su aparente condición de salvador que viene a liberar la energía de creación de su yugo, a curarla de su estado debilitado, permitiéndole reactivarse y volver a manifestarse (2005: 486).

Un complejo vuelco se precipita entre aquellos jóvenes artistas y militantes que durante el período autoritario, a contrapelo del disciplinamiento dictatorial, reactivaron una liberalización creativa y de los modos de vida: jóvenes artistas (en el caso del teatro chileno, en la primera práctica callejera de Andrés Pérez y en la escena teatral y punk concentrada en torno al Trolley, donde Ramón Griffero tuvo un rol crucial) y militantes (el movimiento feminista o el movimiento Lautaro, cuya premisa de «felicidad, erotismo, sexo y alegría» desencajaba de las clásicos mandatos revolucionarios), quienes tuvieron una relevancia central en el proceso de recuperación de la democracia, que, paradójicamente —y de ahí el desengaño- fue crucial para legitimar el nuevo sistema político encargado de implementar el neoliberalismo y su régimen de subjetivación flexible. ${ }^{30}$

En el plano artístico-cultural, el retorno de la «normalidad» trajo consigo un complejo juego de acomodos y reajustes entre institucionalidad, mercado y prácticas artísticas, que modificaron el estatuto crítico del arte en términos de una posición claramente disidente. De ahí que en los noventa, las agrupaciones teatrales ya no se comprenden a sí mismas desde un claro lugar de antagonismo, y que manifiesten un giro más introspectivo (que en el caso de La Patogallina es también retrospectivo, tal como lo expresa la recuperación de eventos históricos en sus obras). De este modo, a diferencia de los grupos más politizados de los años setenta y ochenta, la idea de lo colectivo en La Patogallina, sin prescindir de una ideología común, se distingue sobre todo por proponer una nueva politicidad vinculada a la creación de otros territorios existenciales, que como expresaba el epígrafe, no opone el placer y el deber, la vida y el arte, lo político y lo personal, el individuo y el grupo, la elaboración de la propia identidad y la reapropiación de la «historia nacional».

Un último aspecto a señalar, sobre su constitución como colectivo, que la desmarca de los grupos de creación colectiva de décadas anteriores, es que no se la puede concebir como una compañía tradicional que (sólo) monta espectáculos. En efecto, el año 2000, a modo de sátira a las instituciones culturales, el grupo crea sus «Departamentos de Extensión», que involucran la realización de recitales, programas de radio, organización de fondas y de festivales de cortos teatrales. ${ }^{31}$

hacia el mercado, en «una identificación casi hipnótica con las imágenes del mundo difundidas por la publicidad y por la cultura de masas» (Rolnik, 2005: 482).

30 La idea de un régimen de subjetivación flexible es propuesto por Rolnik en diálogo con el concepto de "personalidad flexible» propuesto por Brian Holmes (2005).

31 Cuyo debut fue la obra El Tercero de Celestina, escrita y actuada por Patricio Pimienta en todos los roles. Parte de estos «proyectos satélite», como los llama también Martín Erazo, son la propia banda La Patogallina Saunmachin - de la que habría que destacar su intervención en la cárcel de Buin en el marco del proyecto dirigido por Mauricio Redolés, Rock y Rejas, el año 2003, que terminó con un disco colectivo de bandas profesionales y de presos-, la obra de teatro de sombras Kresto y su sombra que se originó como acompañamiento a las tocatas de la banda y se concretó como montaje aparte el año 2003 y la obra de danza Gritos de Guerra (2002). También eventos vinculados a la autogestión como la Fonda por la Razón o la Kresta (1999 y 2001), el programa en Radio Tierra, el año 2001, La Patogallina en la tierra y 
Recogiendo los hilos que hasta aquí hemos trazado, podemos también volver ahora a la cita de Oyarzún y Opazo al comienzo de este ensayo, para apuntar que si bien lo señalado por los autores es valioso como gesto de filiación entre lenguajes teatrales de distintas generaciones, no deja de ser cierto que señalar únicamente estos referentes, neutraliza otros aspectos más radicales de las prácticas, las obras y la concepción de lo grupal de La Patogallina, vinculados a la reactivación de otros legados - el arte muralista, el teatro callejero de los ochenta, la intervención artística en eventos políticos, el movimiento de malabaristas, el rock- que contribuyen a perfilar de modo aun más complejo y no exento de contradicciones, la performatividad de sus prácticas y acciones teatrales.

\section{EL HÚSAR DE LA MUERTE}

La primera obra de La Patogllina, A Sangre e Pato (1996-2000), era un montaje callejero de creación colectiva basado en la improvisación, que no tenía un eje dramático determinado, si no en permanente redefinición. Contaban con una escenografía mínima, utilizaban sangre, plumas de ganso - en ocasiones, incluso huevos que se arrojaban al público-; elementos que la emparentaban al happening. Tenía una estética violenta que retomaba la visualidad del comic, la música rock y un trabajo actoral que se sostenía en técnicas del clown y el nuevo circo. La obra fue exhibida en diversos escenarios, entre los más recurrentes, El Centro de Arte Experimental La Perrera y la plaza Juan Sebastián Bach. Además, aunque A Sangre e Pato pasó desapercibida como obra teatral para el campo nacional, fue con ese montaje que el colectivo intervino por primera vez en festivales internacionales: en 1998 en el X Festival de Teatro Iberoamericano de Bogotá, y en 1999 en el II Festival Internacional de Teatro de Santo Domingo, en República Dominicana.

En el año 1999 realizaron junto a algunos miembros del grupo alemán Antagon Theatre Aktion, con quienes estrecharon vínculos en el festival de Bogotá, la intervención urbana Mapocho no olvida, la cual se montó en el puente Los Carros, entre avenida Independencia y Recoleta. Pero fue con la siguiente obra, El Húsar de la Muerte, que el colectivo logró visibilidad en el campo local. La obra se estrenó en julio del año 2000, en la Cúpula del Parque O’Higgins. El proceso creativo se realizó de forma autogestionada, involucró la entrada de nuevos integrantes ${ }^{32}$ y los ensayos fueron en una primera etapa en La Perrera, y luego en el Museo de la Solidaridad Salvador Allende.

Este montaje, en un gesto de recuperación de nuestra memoria audiovisual, estaba basado en la película muda El Húsar de la muerte (1925), de Pedro Sienna. El material fílmico fue el punto de partida dramático y visual de la obra — a diferencia de la obra de Celedón, donde el texto literario sigue estando a la base de la puesta en escena, aunque enmudece ${ }^{33}$ - El concepto plástico se definió en una gama de blancos y negros y la actuación se inspiró en los movimientos entrecortados de las filmaciones de principio de siglo y en los códigos de la pantomima.

actividades en colaboración con otros grupos teatrales como los Festivales de Kortos Teatrales, realizados en La Perrera y en La Quinta Normal de forma autogestionada entre 1999-2003.

32 Entre ellos, el actor Antonio Sepúlveda, quien tendrá un importante rol en el diseño de vestuario y la actriz Sandra Figueroa.

33 Como sucede en Malasangre (Rizk, 2001, cap. III). 
El proyecto teatral fue pensado como un doble tributo: «es un homenaje a Pedro Sienna y también a Manuel Rodríguez, por quien tenemos una gran admiración, hacia su lucha y hacia todos aquellos que le siguieron después» (Erazo en Bernales, 2000: 46). La investigación histórica y el interés por entregar una opinión sobre hechos que marcan puntos álgidos en el escenario de disputa por las representaciones de la historia nacional - como el papel jugado por Manuel Rodríguez en el proceso de Independencia de Chile, o la Matanza de Santa María de Iquique, en 1907, el año de la flor negra (2004)_, son algunos de los principales motores creativos del grupo. Así, aunque la figura de Rodríguez ha inspirado diversas obras del teatro chileno desde el siglo XIX, para los miembros de La Patogallina constituía una figura postergada, ${ }^{34}$ que valía la pena remirar desde otras coordenadas de sentido.

A diferencia de aquellas representaciones arcaicas o carnavalescas del pueblo, que en torno a una recuperación de lo festivo y la oralidad popular caracterizaron algunas obras de Andrés Pérez (Villegas, 2005: 227), en esta obra lo popular, despojado de oralidad, se recupera más bien desde una dimensión combativa - Manuel Rodríguez también se asocia a toda una tradición política de izquierda que lo ha tomado como ícono-. En una impronta épica, son una cierta astucia y habilidad del sujeto popular, las que buscan ser resaltadas, mostrando que la heroicidad, la lucha, no son solo patrimonio de próceres, sino también de aquellos sujetos anónimos que forman parte de los procesos históricos. Así lo expresa la representación de los campesinos que conformaban las montoneras organizadas por Rodríguez, y más adelante con mayor énfasis, también los obreros salitreros en 1907, el año de la flor negra - lo que podría verse como otra diferencia con el teatro de Celedón, que enfatiza en el «personaje» histórico. ${ }^{35}$

Este enfoque sobre lo popular, sobre identidades colectivas que eclipsan la auratización de personalidades individuales, como eje temático e ideológico de algunas obras del grupo, tiene también un correlato en la figura de los "tramoya en escena", que antes que un actor-artista, presenta a un actor multifacético que se multiplica en escena, asumiendo más de un personaje y desempeñándose a la vez como técnico que contribuye al despliegue escenográfico de la obra. Como señala Eduardo Moya, «el actor se convierte en obrero, dentro de la misma escena» (EM). Esta figura remite también a la anulación de la distinción entre «técnicos» y «actores» instalada en el colectivo, aspecto que se traslada como signo metateatral al interior de las obras.

Los códigos expresionistas, el blanco y negro, se expresan también en un mensaje directo, sin dobles lecturas (la obra expone claramente su punto de vista al mostrar un Manuel Rodríguez asesinado por Bernardo O’Higgins); pero en clave paródica, con una mirada lúdica y cargada de humor, que contrasta con la gravedad del discurso de un arte ilustrativo o de concientización. En esta misma línea, la obra contaba con la introducción de íconos contemporáneos - el periódico The Clinic, una fotografía de Augusto Pinochet- que operaban como elementos distanciadores, como breves irrupciones de la realidad contemporánea del espectador. La fotografía del ex-dictador, además, permitía reconectar, a partir de la impronta fundacional de ambos momentos, el contexto de la Independencia con el escenario dictatorial, esbozando cómo, ya en el «momento funda-

34 Patricio Pimienta señala: «Yo fui educado por el gobierno militar, y nunca me hablaron de Manuel Rodríguez como un héroe patrio». Citado en: "La exitosa compañía teatral tira la casa por la ventana en Matucana 100. Los incendiarios cacareos de La Patogallina». Las Últimas Noticias, 2/01/2005.

35 Por ejemplo, Rimbaud en Malasangre, La Reina Victoria, Rasputín, Lénin, Stalin, Freud, Einstein, Hitler, en Taca Taca Mon Amour, Artaud, en Nanaqui. 
cional de la patria», se anunciaban dos tradiciones políticas contrapuestas, vigentes hasta la actualidad.

En El Húsar de la muerte la palabra pronunciada era reemplazada por otras múltiples estrategias discursivas que acentuaban los elementos "performativos» de la obra: la introducción de sonido pre grabado (banda electroacústica de tráfico urbano al comienzo del montaje), la banda de rock en vivo que interviene o comenta la escena (relevando al tradicional pianista de las proyecciones del cine mudo), la utilización dramática de objetos (donde llama la atención la presencia de lo animal: plumas de ganso, una cabeza de chancho); el desborde del gesto pantomímico, la citas visuales a elementos contemporáneos (los ya mencionados The Clinic y el retrato de Pinochet). Todos ellos, elementos que multiplican, acercan, distorsionan, refieren, corporizan lo «real», "desde» la ficción (Hurtado, 2006).

\section{PLUMAS EN LA MONEDA}

Si con A Sangre e Pato el grupo consiguió un prematuro reconocimiento en importantes festivales latinoamericanos, será con El Húsar de la Muerte que el grupo cobrará visibilidad en el campo teatral nacional. Pero lo hizo de un modo heterodoxo, con una intervención cuyos efectos, desbordando incluso la intencionalidad de los miembros del colectivo, atravesaron los criterios estrictamente artísticos de distinción y reconocimiento (Bourdieu, 2003), haciendo ingresar en un espacio definido como teatral, las disputas y agitaciones de la coyuntura política.

La apertura de la VIII versión del Festival Internacional de Teatro a Mil ${ }^{36}$ se celebró el 2 de enero del 2001 en La Moneda, en un evento encabezado por el presidente Ricardo Lagos, que convocaba a los principales actores, dramaturgos, directores y críticos del campo teatral. Así, La Patogallina, invitada a abrir el evento, inauguraba simultáneamente con El Húsar de la Muerte, el FITAM y La Casa de Gobierno como escenario teatral.

La concurrencia de estas dos «inauguraciones», debe entenderse en el contexto de una serie de medidas implementadas por el gobierno para fortalecer simbólicamente el lazo entre el ejecutivo y los ciudadanos; es decir, para restablecer la imagen de La Casa de Gobierno y su entorno, como un espacio público, social y cultural, accesible y receptivo a la ciudadanía. Entre dichas medidas estaba, en efecto, la (re) apertura de La Moneda al tránsito de los peatones a 30 años de su clausura, ${ }^{37}$ a modo de expresión «de la proximidad que tiene que existir entre gobernantes y gobernados» (Squella, 2005: 40). También forman parte de esta "política de reapertura», diversos eventos culturales, tanto aislados como regulares que se realizaron desde el año 2001, en diversos recintos de La Casa de

36 Una de las principales instancias de legitimación del teatro chileno, que al mismo tiempo, esboza la idea de un desarrollo sustentable de teatro a partir del turismo y la inserción del teatro chileno en el mercado teatral internacional, postulándose como «recurso» para revitalizar las economías locales (Yúdice), tal como señala Carmen Romero: «Nos hemos instalado como un atractivo cultural y turístico permanente» (El Mercurio, 27 de enero 2008, E12). Para ver su evaluación revisar: http://www.stgoamil.cl/stgo/.

37 El 13 de marzo del 2000 Ricardo Lagos reabre la Moneda a la ciudadanía. La Casa de Gobierno fue clausurada en 1969 tras el movimiento militar encabezado por el general Roberto Viaux Marambio, conocido como «el Tacnazo», exigiendo mejoras salariales para el ejército y la renuncia del ministro de defensa Tulio Marambio. 
Gobierno, como exposiciones, recitales de orquestas juveniles y exhibición de películas emblemáticas de la filmografía nacional (Squella). ${ }^{38}$

En contraste a lo señalado por Agustín Squella, Gabriel Salazar (2005), señala que durante el gobierno de Ricardo Lagos, La Moneda no fue sede de grandes concentraciones de masas en apoyo al gobierno o a alguna reforma política estructural - como podría haber sido la convocatoria a la población a ejercer sus poderes soberanos en la elaboración de una nueva y legítima Constitución, que releve a la impuesta por la dictadura $^{39}$ - Sólo se vio ocupar polémicamente las grandes alamedas, a protestas de grupos particulares, ${ }^{40}$ ninguno de los cuales dejó de ser reprimido por las fuerzas especiales de Carabineros, incluso, llegando a invocar en algunos casos, la Ley Anti-terrorista, lo que para Salazar, se traduciría en «una separación —y no solo territorial— entre el Estado y el bajo pueblo (2005: 97).

Es interesante notar que las iniciativas resaltadas por Squella se acercan más al orden de lo estético que de lo estrictamente político. La idea de restaurar el vínculo entre "gobernados y gobernantes» a partir de eventos rituales — como la reapertura de la puerta de Morandé $80-$ y de expresiones culturales y artísticas, produce una forma particular de consenso, que no necesita de un contenido político acotado, que pueda ser debatido, o producir discrepancias. Al constituirse sólo como experiencias estéticas, antes que argumentos o consignas partidistas, producen sentimientos y afectos que apelan a la interioridad ${ }^{41}$ de cada sujeto y pueden constituirse como "experiencias de puro consenso sin contenido» (Eagleton, 2006: 156), en la medida en que no se imponen, ni necesitan de la mediación de la persuasión. Por supuesto, lo estético es un concepto en sí mismo contradictorio, en tensión permanente, que no sólo contiene momentos de alienación; sino también una potencialidad crítica, liberadora. Pero aquí, inscrita en la «ideología de un consenso sin fisuras", la cultura adquiere la entidad de una esfera que "promueve una unidad íntima y sin constricciones entre los ciudadanos a partir de su más profunda

38 Squella señala: «la propia Moneda acogió también distintas expresiones artísticas y culturales, con lo cual me refiero no solo a actividades aisladas, si bien relevantes — como la inauguración de la octava versión del Festival Teatro a Mil, el 2 de enero del 2001, la exhibición ante una gran cantidad de público, de El Húsar de la muerte, de Pedro Sienna, el Día Mundial del Cine de 2002, y la bellísima actuación del coro de la Universidad Técnica de Szczeni, un mediodía de verano, también el 2002_, sino a programas culturales de tipo regular que se desarrollaron en diversos recintos de la casa de gobierno durante el curso de los últimos años, a los que nos vamos a referir más adelante, y que vinieron a complementar la decisión inicial del Presidente Lagos en orden a abrir La Moneda al paso de los ciudadanos»: (2005: 43).

39 En efecto, el 17 de septiembre, el mismo día que inaugura los tijerales del Centro Cultural de La Moneda, Lagos promulgó reformas constitucionales y un nuevo texto que sistematizaba todas las reformas hechas a la Constitución impuesta por la dictadura, sin hacer ningún cambio al sistema binominal. Como señala Garretón, la consecuencia de ello fue que el presidente Lagos «clausuraba el debate nacional en torno a la necesidad de que el país genere su propio consenso sobre su modo de convivencia y la organización del poder, que es básicamente una constitución» (2006: 178).

40 Salazar menciona que «se registraron movimientos estudiantiles (secundarios y universitarios), étnicos, antiglobalización, de género y de recordación funeraria o ritual» (2005: 95).

41 En su análisis, Eagleton está tomando como referencia la estética kantiana. De ahí que dicha «interioridad», remita a la intersubjetividad propia del juicio estético. Como señala Eagleton: «La estética no es en modo alguno cognitiva, pero tiene consigo algo que se asemeja a la forma y estructura de lo racional; por tanto desarrolla vínculos con toda la autoridad de la ley, pero en un nivel más afectivo e intuitivo. Lo que nos conforma mutuamente como sujetos no es el conocimiento sino una inefable reciprocidad en el sentimiento. Y esto es ciertamente, una razón de peso por la que la estética ha aparecido de una manera tan central en el pensamiento burgués: lo preocupante de esta verdad es que, dentro de un orden social marcado por la división de clases y el mercado competitivo, sobrevendrá finalmente aquí, y solo aquí, el hecho de que los seres humanos sean mutuamente miembros de una misma comunidad» (2006: 133). 
subjetividad», mientras que la política, queda naturalizada como el ámbito «restringido al comportamiento público y utilitario» (157).

En ese sentido, la imagen que se busca restituir de La Moneda no es aquella que erige La Casa de Gobierno como el lugar donde «se hace la política» (pues ello la convierte inevitablemente en un escenario de disputas), al cual los ciudadanos pueden acudir para apoyar o repudiar al gobierno, manifestar y expresar sus propuestas. La imagen que se busca es otra: la de un lugar inmaculado, donde residen aquellos que «representan», un lugar que puede ser cotidiana y despersonalizadamente atravesado, recorrido, incluso habitado en instancias artístico-culturales por los ciudadanos, como una forma de alimentar periódicamente el poder simbólico de sus representantes, entablando un vínculo tremendamente cercano y distante a la vez. Las forcejeos y roces de lo político están en otro lugar, ahí, la única relación política efectiva, es aquella indirecta y anónima que se actualiza en las urnas, a través del voto (y ello, en el marco de un orden jurídico regido por la Constitución de 1980). La redefinición de la democracia se hace entonces a puertas cerradas, en un proceso que definen privadamente unos pocos privilegiados, en el cual la participación cívica de la ciudadanía en términos mayoritarios está vedada.

Tendremos entonces a la vista a esta "política de apertura» de La Moneda puesta en práctica por el gobierno, a la hora de revisar como transcurrió la jornada de inauguración del FITAM (que podría verse como uno de los primeros hitos de dicha "política»).

En el marco de las polémicas que ese año se desataron en torno al juicio a Augusto Pinochet, las tensas negociaciones entre el ejecutivo y las fuerzas armadas, llevaron al gobierno a convocar al Consejo de Seguridad Nacional (COSENA — creado por la Constitución Política de 1980-), instancia donde los militares tenían el objetivo de pedir la aplicación de la ley de Amnistía al ex-presidente de facto. En ese contexto, diversos grupos de derechos humanos, el Partido Comunista, la CUT (Central Unitaria de Trabajadores), distintos sindicatos y agrupaciones, ${ }^{42}$ llamaron a una manifestación en oposición tajante al accionar del gobierno, pues entendían al COSENA como un resabio dictatorial.

Por su parte, la prensa describió el acontecimiento que hizo coincidir el hecho político y el hecho cultural:

Finalizada la tarde y a la espera del término del COSENA en La Moneda, se vivió una escena propia de Ionesco. Mientras en el segundo piso civiles y militares analizaban complejos problemas de derechos humanos, el Patio de Los Cañones se repletaba con actores y actrices que $[. .$.$] llegaron para participar en el VIII Festival Internacional de Teatro a Mil».{ }^{43}$

Aparece así la posibilidad de pensar el espectáculo de La Patogallina, como el cruce entre los tres eventos: la protesta ciudadana, la reunión del COSENA y la inauguración del FITAM, constituyéndose en un evento que nos permite repensar la relación entre arte y política, de un modo que no circunscribe la efectividad de dicha relación a "la obra» (concebida como artefacto).

Desmarcando nuestra lectura de aquellas que ven la política como algo subordinado al arte; como si la política fuera algo que llega por añadidura al arte como «tema», o

$42 \quad$ Las protestas dirigidas por el partido comunista y diversas organizaciones de derechos humanos, fueron precedidas por un grupo de gremios y organizaciones sociales que se autodenominaron COSENA Cívico, que por su parte, contó la participación de representantes de los colegios de Profesores, de Periodistas, de la Central Única de Trabajadores (CUT) y de la Asociación Nacional de Empleados Públicos, entre otras. Véase La Tercera, 3 de enero, p. 6.

43 En: «Lagos: Inauguramos Teatro a Mil», La Nación, 3/01/2001, p. 3. 
bien, que entiende lo revulsivo en lo artístico como efecto en un plano formal y a la vez "discursivo" de la obra, lo que nos interesa es pensar la exhibición de El Húsar de la Muerte en La Moneda como "acontecimiento» inscrito en el espacio social. Es decir, no sólo como "obra» sino como un evento que, incrustado en un contexto preciso y con toda su performatividad, permite reformular tanto la noción de arte como de la política (poniendo en tensión el presupuesto moderno de una autonomía del arte).

Antes de iniciar la función de El Húsar de la Muerte, los músicos del grupo hicieron un homenaje a Salvador Allende: entraron con una bandera chilena, una fotografía del ex presidente de la Unidad Popular y amplificaron, por altoparlantes, un poema de Pablo de Rokha. Una vez instalados, en un gesto no planificado, algunos músicos pronunciaron gritos alusivos a la disputa judicial en torno a Augusto Pinochet.

Este hecho constituye más que una simple anécdota, si pensamos que, si bien La Moneda se abrió a la circulación de peatones y a actividades culturales, el lugar de la protesta se ha circunscrito, históricamente, a sus extramuros. Así, mientras que los manifestantes y su demanda ciudadana en torno al COSENA permanecen literalmente afuera de La Casa de Gobierno - pues la manifestación no se traduce en negociación ni diálogo-, el montaje se instala en su centro, como expresión artística. Algo se desestabiliza en el momento en que los músicos de La Patogallina señalan, con sus gritos alusivos a Pinochet, ese «afuera» y convierten así el evento teatral en un reclamo ciudadano. Al mismo tiempo, logran con ello fisurar la posición en que la oficialidad los busca ubicar, ejerciendo un descentramiento al hacer explícita «la escena propia de Ionesco» que protagonizaban junto a los agentes más relevantes del campo teatral. Intervienen así efectivamente ese espacio, lo que imposibilita la contemplación meramente estética y desinteresada de la obra, como si el escenario en que se convierte La Moneda fuera un mero sucedáneo de la sala teatral. Al trazar un puente entre ficción y coyuntura, entre el adentro y el afuera de La Moneda, la breve manifestación, y la obra, fracturan la idea de ese espacio como un espacio de consenso.

Así, La Patogallina (colectivo que como hemos visto, desde un lugar discordante, en tensión, hunde raíces en la resistencia cultural de la izquierda en los ochenta), irrumpe en La Casa de Gobierno en la precisa coyuntura que reactualizaba el conflicto en torno a los derechos humanos a propósito del juicio a Augusto Pinochet, ejerciendo un corrimiento tanto del mandato de la política de la izquierda tradicional (el recurso de la protesta que afirma como trinchera el afuera de La Moneda), como de los mandatos del arte (lo político como tema, o como disrupción formal «de la obra»). Esta irrupción —cuya complejidad no alcanza a comprenderse como hecho aislado, sino teniendo a la vista el itinerario de la prehistoria del grupo, aquí trazado- podría entenderse, en términos de Vilensky (2007), como la constitución de una "contra esfera pública», de una zona que "desafía simultáneamente lo que la sociedad acepta como política y lo que el arte acepta como estética» (57).

La Patogallina instaló la protesta ciudadana en el centro de La Casa de Gobierno, restituyendo así un sentido de lo político que hace de ese espacio cultural un espacio divergente, de no-consenso. El colectivo buscaba traer al presente una parte de la historia de La Moneda, con la imagen de Allende. Y terminó visibilizando, en su «cita» a la protesta ciudadana (los gritos alusivos a Pinochet y por añadidura al COSENA), las distintas partes de un conflicto de la coyuntura política que tomaba como escenario, ese día, a La Casa de Gobierno (a propósito del caso Pinochet) "porque» la había tomado como escenario hace treinta años, con el Golpe de Estado. Se ponía en práctica un gesto de reacti- 
vación de la memoria, que, a su modo, la obra El Húsar de la Muerte, desde sus propios códigos teatrales, también ponía en marcha. Pero también, la "cita» a los manifestantes en el exterior de La Moneda, produjo un descontrol, ${ }^{44}$ una operación de desestabilización y desplazamiento de las prohibiciones y las distribuciones espaciales con las que el gobierno ordenaba el lugar de la protesta ciudadana y los términos del disenso.

Fue entonces, con una acción heterodoxa, inhabitual dentro del campo, que La Patogallina se apropió de una instancia de legitimación que la hizo merecedora de un lugar distintivo y reconocido entre sus pares.

Aun así, para los miembros de La Patogallina este evento no dejó de estar atravesado por contradicciones y sentimientos encontrados. Y es que en realidad, el evento fue, en muchos sentidos, contradictorio. Por una parte, Rodrigo Rojas, señala un aspecto que, fuera de toda precaución moralizante, parece importante no dejar de señalar:

El Húsar nos abrió las puertas al mundo del estrellato, por así decirlo, al mundo del teatro, porque a nosotros nadie nos conocía, pasamos cinco años inadvertidos haciendo teatro callejero [...] cuando actuamos en La Moneda, el año 2001, ahí nos vieron los ministros, la gente, todos nuestros pares de teatro que no nos conocían (RR). ${ }^{45}$

De alguna manera, este evento otorga visibilidad, concede una tribuna a la propuesta estética e ideológica del colectivo.

Por otra parte, Gloria Salgado pone énfasis en las dudas que se generaron al interior del colectivo respecto a la intervención en eventos oficiales:

Yo en este momento no me acuerdo cómo fue la decisión de estar ahí, pero sí me acuerdo que nos cuestionamos mucho si lo hacíamos o no lo hacíamos, si hacíamos cosas para el gobierno o si no lo hacíamos. Ahora, nosotros aprovechamos la instancia para conmemorar gente que había estado ahí, a Allende, a gente buena que estuvo ahí en el gobierno (GS).

Por su parte, respecto a la disyuntiva de si realizar o no una intervención como algo adicional a la obra, Martín Erazo remarca que, aunque el colectivo respaldaba la idea de hacer un homenaje a Allende, la intervención propiamente dicha, fue iniciativa de los músicos:

A los músicos les vino la idea y la hicieron, pero no fue algo organizado como compañía [...] en el fondo todos lo apoyábamos, no es que hubiera un conflicto adentro. Salió toda la coyuntura de lo que estaba pasando, pero también era una cosa histórica estar ahí. Lo único que sí teníamos acordado, era que íbamos a poner una bandera con la foto de Salvador Allende y la Canción Nacional (sic), pero después pasaron otras cosas, algunos gritaron cosas, sobre el juicio de Pinochet. Pero se dio así y mucha gente lo entendió bien, otra gente gritó también (ME2).

Hubo así posiciones encontradas que dan cuenta, en distintos niveles, de lo complejo que fue para el colectivo tomar la decisión de formar parte y cómo hacerlo en la inauguración del FITAM. La decisión además no estuvo libre de ciertos costos: después de

44 Fue una acción incontrolable para las autoridades políticas y los organizadores del evento, pero también para el colectivo, pues los gritos, y sus efectos excedían toda planificación previa (considerando además, que el homenaje a Allende se ideó sin saber que la inauguración del FITAM coincidiría con una jornada de protestas).

45 Entrevista a Rodrigo Rojas, noviembre 2006, en el marco del proyecto Fondart $n^{\circ} 48927$. 
la función, se produjo un conflicto con la productora organizadora del evento que los convocó, Romero \& Campbell, que reprobó la intervención previa al montaje. A todo ello, se añadió que durante la fiesta que se hizo después de la función, se produjeron algunos desmanes en distintos sectores de La Casa de Gobierno, lo que fue aprovechado por la prensa para desvirtuar la imagen del colectivo. ${ }^{46}$ Así, haciendo un balance de la experiencia, Gloria Salgado agrega: "yo creo que era un momento importante, pero no dejó de estar como teñido de mucho protocolo y de estar muy disfrazado aún, muy disfrazado» (GS).

Para terminar, nos interesa remarcar un aspecto fundamental, que resignifica este evento, permitiendo amplificar su sentido más allá del hecho puntual. Salgado señala:

Para mí es tan importante hacer una función así, como cuando fuimos a San Pedro, un pueblito, con gente que nunca había visto nada de teatro. También eso es abrir un espacio, también eso es como abrir La Moneda, o más quizá, porque es gente que nunca más a lo mejor va a ver teatro, o que quizá van a pasar varios años para volver a ver otra cosa. Entonces tampoco lo sobrevaloro demasiado (GS).

Hay una lucidez y una habilidad, en las que resuenan los ecos de la pre-historia del colectivo, para poder disolver las estrategias de «distinción» y la creencia en los juegos de reconocimiento estrictamente artísticos — la illusio, en términos bourdianos-, que le permite al colectivo, no sin costos ni contradicciones, ganar "autonomía» en su interacción con las instancias de consagración del campo.

\section{CODA}

La acción de La Patogallina en La Moneda generó un extrañamiento de la teatralidad convencional, pues puso en marcha un dispositivo estético que activó una dimensión macropolítica, propia de un conflicto coyuntural - la reunión del COSENA- que removía tramas de la memoria colectiva y desestabilizaba la disposiciones territoriales del adentro y el afuera de la Casa de Gobierno. El gesto político se volvió indiscernible del gesto artístico, haciendo emerger un espacio «liminal». Citando dispositivos de la protesta (la pancarta, la fotografía, el grito y la consigna), los músicos de La Patogallina revistieron la obra ficcional de un "conflicto político real», para exigir a las autoridades ahí presentes junto a actores y directores teatrales, que se hiciera justicia en relación al caso Pinochet. Quizá este signo de demanda, permite leer la performatividad de la acción desde un ímpetu más restitutivo que reconstructivo. ${ }^{47}$ Pero también, admite ser leído como un

46 Martín Erazo cuenta: «fue como la primera vez que se abrió La Moneda a los artistas en general y yo creo que todos se volvieron un poco locos en ese sentido. Y después nos cargaron toda la cuestión a nosotros. Incluso creo que el cura llegó al otro día a la capilla y había algodones, cosas de teatro, deben haber habido vasos con copete, montón de cosas. Y después salió que había sido un sacrilegio, pero todo lo había hecho La Patogallina, no nombraban al resto de la gente que había estado en la fiesta, porque era una fiesta en el fondo" (ME2).

47 Tal como sucede en el análisis que el propio Yúdice realiza sobre las Madres de la Plaza de mayo. El autor señala que ellas «se invistieron con todos los atributos de los valores de la familia, la maternidad y la solicitud personalista, no para burlarse o deconstruirlos, sino para avergonzar a los militares y obligarlos a cumplir con estos valores [...] Más que cuestionar el papel desempeñado por la familia y su impacto en las esferas públicas, exigieron que se cumpliera un pacto preformativo tradicional» (2002: 96). 
desborde y desafío de los mandatos del arte tanto como de los de la política, que habría trocado el espacio normalizado de consenso en un territorio de disputa.

Esta acción con que La Patogallina adquiere visibilidad en el campo cultural, es a la vez indisociable de lo que podríamos denominar "política de exhibición nómade», un modo de situarse en el campo cultural, entendido en términos de flujos que bordean, rodean, rompen o fisuran las articulaciones predeterminadas de los espacios institucionales — teatrales, políticos- produciendo una «topografía otra», en permanente redefinición y transformación. Dicha política se expresa por un lado, en la imagen de la montonera, como imagen de velocidad y metamorfosis, tal como la recuperan los propios miembros del grupo en su discurso:

Con el Húsar de la Muerte, entendimos que nuestro camino era hacer historia. Teatrohistoria. Y más que historia propiamente tal, era recuperar la historia enterrada, la historia olvidada. Que tiene que ver con el Manuel Rodríguez guerrillero, que organizó las montoneras, que se disfrazaba para hacer lesas a las autoridades. Nos cautivó que él se disfrazaba, tenía todo un cuento teatral para combatir (CC1).

La imagen de las montoneras, asociada a Manuel Rodríguez, lleva inscrita la idea de movilidad pero también la de beligerancia y asalto; de un grupo que cambia el uniforme del ejército por el disfraz que carece de los emblemas patrios, pero es portador de una «identidad política» no oficial; y cuya ocupación territorial implica desorden, proliferación, pero objetivos focalizados. La apropiación que el colectivo hace de esta imagen, parece poderosa y efectiva para comprender el modo cómo el colectivo irrumpe con El Húsar de la Muerte en La Moneda.

Por otro lado aparece, en afinidad con la figura rodriguista, la imagen del «teatro móvil» como estructura teatral ambulante. Ésta encuentra ecos en el circo o el antiguo teatro ambulante de feria, retomado también por las vanguardias históricas —agit prop en Rusia y Alemania, Meyerhold-:

Nuestras obras tienen estructuras que no necesitan nada para sostenerse. Las escenografías de nosotros se pueden armar en cualquier lugar y por eso son grandes, porque es como un teatro móvil, tiene las cuerdas, lo que podría haber dentro de un teatro (ME2).

Pero no se trata sólo de una estructura que pueda moverse «a» distintos lugares, sino que tiene la capacidad de yuxtaponer en propia estructura, múltiples espacios a veces incompatibles entre sí, produciendo desplazamientos aun en estado de quietud. ${ }^{48} \mathrm{La}$ idea de un teatro móvil como «estructura autosuficiente», podría entonces pensarse en sí misma como un espacio heterotópico que se instala cada vez, al modo de "contra-emplazamientos, especies de utopías efectivamente realizadas, en las cuales los emplazamientos reales que se pueden encontrar en el interior de la cultura están a la vez representados, cuestionados e invertidos» (Foucault, 1984: 2).

El teatro móvil hace posible una diversificación de los movimientos que se sintetizan en la premisa de «cubrir todos los frentes»:

48 Como sucede en el Húsar de la muerte, por ejemplo, con la intersección de distintas temporalidades: elementos que refieren el mundo contemporáneo del espectador, que interrumpen la temporalidad de la ficción, anclada al contexto de la Independencia. O más adelante, emblemáticamente en 1907, el año de la flor negra, donde el escenario, al modo de una máquina escénica, produce múltiples espacios ficcionales. 
El problema no es no actuar en salas sino actuar en todos los lugares, actuar en galpones, en la calle, en teatros. Y yo creo que nosotros hemos tratado de adaptarnos a la realidad latinoamericana, a una realidad chilena. Para nuestro espectáculo no hay tantas salas donde uno pueda actuar, si hay espacios públicos, en el sur uno puede actuar en galpones, en el norte en una plaza; pensamos en la mayor cantidad de gente que nos pueda ver (ME2).

Hay aquí una noción ampliada de espacio público, entendido como un espacio en disputa, que no se restringe a la calle, o a espacios abiertos, sino, retomando la imagen de las montoneras, a distintos espacios susceptibles de ser tomados por asalto, tal como sucedió, podríamos pensar, en La Moneda. Ello plantea una relación distinta con los espacios institucionales, pues expresa, como señala Vilensky, que «la táctica que hoy parece tener mayor potencial es no tener que elegir entre el entrismo y el éxodo de la institución, sino más bien utilizar estas dos estrategias simultáneamente» (2007: 60). Así, Martín Erazo señala:

Como colectivo nosotros entramos de repente en algún teatro, o entramos en ciertos circuitos que hace el gobierno, eso no significa que perdamos la independencia. Para mí la independencia, son grupos que se sustentan, que tienen su presidente, su tesorero, su lugar de trabajo, su nombre y que no le da cuentas a nadie» (ME2).

En efecto, el teatro móvil, pensado como heterotopía, no es ni el adentro ni el afuera, sino un "espacio otro", un espacio de autonomía que opera en una topografía propia, en permanente transformación. No sin costos ni negociaciones, esta modalidad abre la posibilidad de pensar otros territorios para las prácticas escénicas, no regidos ya por la lista de estrenos de las salas convencionales, los catálogos de festivales o las miradas de los veedores de teatro, sino como una forma de insertarse en la red de acontecimientos que van definiendo la trama social, sin quedar restringido a las miradas estéticas. Las imágenes nómades de un teatro móvil y de las montoneras, configuran la política de exhibición de La Patogallina no sólo como fisura a la economía de recepción y circulación de las obras, que las circunscribe a las salas de teatro, o a espacios donde la convención de lo teatral ya ha sido instaurada, sino también, como desacato a las territorialidades de lo político.

\section{REFERENCIAS}

Bernales, Paola. (2000). Alto contraste: El teatro en blanco y negro. Rocinante 20. Septiembre, p. 46.

Bourdieu, Pierre. (2003). Creencia artística y bienes simbólicos. Elementos para una sociología de la cultura. Buenos Aires y Córdoba: Aurelia Rivera.

Contardo, Oscar y Macarena García. (2005). La era ochentera. Tevé, pop y under en el Chile de los ochenta. Santiago: Ediciones B.

Corbeira, Darío y Marcelo Expósito. (2005). Arte: la imaginación política radical. En Brumaria 5, verano 2005. Obtenido desde: <http://eipcp.net/transversal/0106/brumaria/es>. 
Costa, Mario. (2002). El teatro callejero en Chile: la emergencia de decir y hacer, 19801990. Tesis para optar al título de actor. Pontificia Universidad Católica de Chile, Santiago.

Diéguez, Ileana. (2007). Escenarios liminales. Buenos Aires: Atuel.

- (2004). Fronteras entre vida y arte. Teatralidad y performance en la escena latinoamericana. Palos y Piedras. Revista de política teatral, Año II, 2: 36-48. Noviembre.

Eagleton, Terry. (2006). La estética como ideología. Madrid: Editorial Trotta.

Ficher Lichte, Erika; Roselt, Jens. (2008). «La atracción del instante. Puesta en escena, performance, performativo y performatividad como conceptos de la ciencia teatral». En Revista Apuntes 130: 115-125. Pontificia Universidad Católica de Chile.

Foucault, Michel. (1984). De los espacios otros «Des espaces autres», Conferencia dictada en el Cercle des études architecturals, 14 de marzo de 1967. En Architecture, Mouvement, Continuité, 5. Octubre. Traducida por Pablo Blitstein y Tadeo Lima. Obtenido desde <http://www.scribd.com/doc/4650039/Foucault-M-De-los-espaciosotros>.

Garretón, Manuel Antonio. (2006). Del postpinochetismo a la sociedad democrática. Globalización y política en el bicentenario. Santiago: Debate.

Griffero, Ramón. (1992). Radiografía de una dramaturgia. Apuntes 103: 93-98 (primavera 1991 - otoño 1992).

Holmes, Brian. (2005). La Personalidad Flexible. Brumaria 7. Madrid. Obtenido desde: $<$ http://www.brumaria.net/textos/Brumaria7/09brianholmes.htm>.

Hurtado, María de la Luz. (2006). Historicidad en el teatro chileno del dos mil. En Halima Tahan (comp.). Escenas Latinoamericanas. pp. 107-117. Buenos Aires: Ediciones artes del sur.

Lagos, Soledad. (1994). Creación Colectiva. Teatro chileno a fines de la década de los 80. Frankfurt: Peter Lang. Europaischer Verlag der Wissenschaften.

Lehmann Hans-Thies. (2002). Le théâtre postdramatique. Trad. Philippe-Henri Ledru. París: L'Arche.

Longoni, Ana. (1999). Brigadas Muralistas: La Persistencia de una práctica de comunicación político-visual. Revista Crítica Cultural 19: 22-27. Noviembre.

Neira, Hernán y Olga Segovia. (2005). Espacios públicos urbanos: una contribución a la identidad y confianza social y privada. Revista INVI año/vol 20, 55: 166-182. Noviembre.

Oyarzún, Carola y Cristián Opazo. (2008). Viajando y buscando eternamente. La nueva dirección en la escena chilena y sus modelos. Las huellas de los grandes directores y grupos de la década de los noventa. En Theater der Zeit, Chile - Vom Rand ins Zentrum (Chile: de los márgenes hacia el centro). Edición especial bilingüe coordinada por Soledad Lagos. pp.18-24. Berlín.

Pavis, Patrice. (2002). El análisis de los espectáculos: teatro, mimo, danza, cine. Barcelona: Paidós.

Prádenas, Luis. (2006). Teatro en Chile. Huellas y trayectorias. Santiago: Lom.

Ramírez, Felipe. (2004). La Patogallina: teatro punk y máquina sonora. Cazuela mutante. En La Nación, Santiago de Chile, 24 de octubre. Obtenido desde: <http://www. lanacion.cl/prontus_noticias/site/artic/20041023/pags/20041023183607.html>

Rizk, Beatriz. (2001). Posmodernismo y teatro en América Latina: teorías y prácticas en el umbral del siglo XXI. Madrid: Iberoamericana. 
- (2000). El arte del performance y la subversión de las reglas del juego en el discurso de la mujer. Latin American Theatre Review, Spring 2000, pp. 93-111.

Rolnik, Suely. (2006). La memoria del cuerpo contamina el museo. Brumaria 8: 99-114. Madrid.

—. (2005). Geopolítica del rufián. En Felix Guattari y Suely Rolnik. Micropolítica. Cartografía del deseo. Buenos Aires: Tinta Limón.

Salazar, Gabriel. (2005). Ricardo Lagos, 2000-2005: Perfil histórico, trasfondo popular. En Gobierno de Lagos: Balance crítico. Varios Autores. Santiago: Lom.

Salazar, Gabriel y Julio Pinto. (2002). Historia contemporánea de Chile V. Niñez y Juventud. Santiago: Lom.

Squella, Agustín. (2005). El jinete en la Lluvia. Cultura en el gobierno de Lagos. Santiago: Aguilar.

Vilensky, Dmitry. (2007). ¿En qué consiste hoy una exposición política? Trad. Marcelo Expósito. Ramona 75: 57-61. Octubre. Buenos Aires.

Villegas, Juan. (2005). Historia multicultural del teatro y las teatralidades en América Latina. Buenos Aires: Galerna.

Williams, Raymond. (1980). Marxismo y literatura. Barcelona: Editorial Península.

Yúdice, George. (2002). La cultura como recurso. Madrid: Gedisa.

Recepción: enero de 2009

Aceptación: mayo de 2009 